\title{
A Vibrio splendidus strain is associated with summer mortality of juvenile oysters Crassostrea gigas in the Bay of Morlaix (North Brittany, France)
}

\author{
A. Lacoste $^{1}$, F. Jalabert ${ }^{1}$, S. Malham ${ }^{1}$, A. Cueff ${ }^{1}$, F. Gélébart ${ }^{1}$, C. Cordevant ${ }^{2}$, \\ M. Lange ${ }^{2}$, S. A. Poulet ${ }^{1, *}$
}

${ }^{1}$ Station Biologique de Roscoff, Centre National de la Recherche (CNRS), Université Paris VI, 29682 Roscoff, France

${ }^{2}$ Institut Pasteur de Lille, 1 rue du Professeur Calmette, 59019 Lille, France

\begin{abstract}
Juvenile oysters Crassostrea gigas cultured in the Bay of Morlaix (France) have suffered unexplained summer mortalities for over a decade. In the present study, we tested the hypothesis that a bacterial pathogen could be responsible for this phenomenon. A first attempt failed to isolate a bacterial pathogen from moribund or weak oysters. Only non-pathogenic, probably opportunistic, bacteria were isolated. As an alternative approach, we focused on oysters presenting reduced stressresponse capacities (determined by circulating noradrenaline measurements), a characteristic of juvenile oysters entering an early phase of the disease. Cultures of bacterial isolates on TCBS plates revealed that a Vibrio strain was present in diseased oysters and scarce or absent in healthy oysters. Experimental infections indicated that this Vibrio can cause mortalities of juvenile oysters when injected at concentrations ranging from $10^{4}$ to $10^{8} \mathrm{CFU}$ oyster ${ }^{-1}$. Similarly to the summer mortality disease, the Vibrio isolate caused higher mortalities at higher temperatures; apparently, it could not be transmitted horizontally, it did not affect adult oysters and it induced stress-response dysfunctions in juvenile oysters. Phenotypic and genotypic characterizations identified the pathogen as Vibrio splendidus. Taken together, the present results satisfy Koch's postulate and suggest that this bacterial strain is probably responsible for the juvenile oyster summer mortalities in the Bay of Morlaix.
\end{abstract}

KEY WORDS: Crassostrea gigas - Summer mortality - Juveniles · Vibrio splendidus - Stress · Noradrenaline

\section{INTRODUCTION}

Mass mortalities of Pacific oysters Crassostrea gigas have repeatedly occurred in Brittany (France) since the mid eighties. Losses (10 to $80 \%$ of stock) only affect 6 to 12 mo old oysters (so-called 'juvenile' oysters) ranging from 5 to $40 \mathrm{~mm}$ in shell length and 100 to $800 \mathrm{mg}$ dry weight. Older oysters are not affected. Mortalities occur during summer (June to September), when water temperatures exceed $16^{\circ} \mathrm{C}$ (Deslou-Paoli et al. 1982). The disease itself shares several similarities with

${ }^{*}$ Corresponding author. E-mail: poulet@sb-roscoff.fr the so-called juvenile oyster disease (JOD) affecting $C$. virginica stocks cultured in the north eastern United States (Lee et al. 1996). Notably, the mortality episodes last relatively short periods of time (1 to $2 \mathrm{wk}$ ), and factors such as food limitation, oxygen depletion, salinity and temperature variations do not appear to be direct causal agents of the mortalities (Soletchnik et al. 1998, Poulet et al. 2000). Although several causes have been attributed to this type of mortality (Lee et al. 1996), the actual agent of the disease of either $C$. virginica or $C$. gigas remains unknown.

Preliminary experiments had shown that when juvenile oysters belonging to batches suffering high mortality were treated with antibiotic solutions, daily mor- 
tality rates decreased within 24 to $48 \mathrm{~h}$ (Poulet et al. 2000). A similar approach gave similar results when applied to Crassostrea virginica to elucidate the etiology of the JOD (Boettcher et al. 1999, Elston 1999b). In addition, previous studies indicated that 2 to $3 \mathrm{wk}$ before mortalities occur, juvenile oysters showed signs of neuroendocrine system dysfunction. Indeed, the stress-induced noradrenaline (NA) responses were reduced in these oysters (Cueff et al. 2000, Lacoste et al. 2000, Poulet et al. 2000). In the present study, juvenile oysters presenting this early sign were selected to test the hypothesis that a bacterial pathogen was responsible for the juvenile oyster summer mortalities observed in the Bay of Morlaix.

\section{MATERIALS AND METHODS}

Oysters. Twenty batches ( $\mathrm{n} \geq 500$ organisms per batch) of juvenile Crassostrea gigas oysters originating from different hatchery or oyster farm stocks were placed on an experimental field site in the Bay of Morlaix between May and September 1999. They consisted of 2 reference batches, 1 wild-caught batch (named Batch B) and 1 hatchery produced batch (named Batch V), which experienced low mortality $(<5 \%)$, and of 18 other wild-caught or hatchery produced batches which experienced 10 to $65 \%$ mortality (including Batch RRB, which suffered 63.75\% mortality). Juvenile oysters belonging to batches exhibiting $>45 \%$ mortality were termed 'naturally infected' oysters.

Isolation of bacterial strains. A first set of bacterial strains was isolated from 20 to 30 moribund or gaping juvenile oysters belonging to the 20 batches present on the experimental field site. A second set was later isolated from 10 RRB juvenile oysters showing signs of impaired stress-response capacity (see below).

Juvenile oysters (100 to $400 \mathrm{mg}$ dry weight) were removed from their shells and minced in $5 \mathrm{ml}$ of sterile seawater. The resulting solution was vigourously mixed for 1 min using a vortex mixer and centrifuged at $200 \times g$ for $5 \mathrm{~min}$ at $4{ }^{\circ} \mathrm{C}$. The pelletted tissues were discarded and the supernatant was serially diluted $\left(1 / 10\right.$ to $\left.1 / 10^{6}\right)$, spread onto either Zobell (Gibco) or TCBS (Gibco) agar and cultured at 17 to $18^{\circ} \mathrm{C}$ for 24 to $48 \mathrm{~h}$.

Pathogenicity assays. Dominant colonies on Zobell or TCBS plates were isolated and cultured in liquid Zobell (Gibco) for $24 \mathrm{~h}$ at $20^{\circ} \mathrm{C}$. The bacterial cultures were then harvested in sterile seawater. Serial 10-fold dilutions were prepared and juvenile oysters Crassostrea gigas belonging to batches suffering low mortality ( $<5 \%$ mortality) were injected with $10^{4}, 10^{6}, 10^{7}$ or $10^{8} \mathrm{CFU}$ oyster ${ }^{-1}$ ( $\mathrm{n}=20$ to 30 oysters per treatment unless otherwise indicated) in the adductor muscle. In separate experiments, 30 juvenile oysters were incubated in $300 \mathrm{ml}$ of a bacterial suspension $\left(10^{6} \mathrm{CFU}\right.$ $\mathrm{ml}^{-1}$ ) for $30 \mathrm{~min}$. Thirty adult oysters (25 to $30 \mathrm{~g}$ dry weight) were also injected with $10^{6} \mathrm{CFU}$ per oysters in the adductor muscle. Control juvenile and adult oysters ( $\mathrm{n}=20$ to 30 ) were injected with and/or incubated in sterile seawater. Following bacterial injection, test and control oysters were maintained in separate polyethylene tanks containing $110 \mathrm{l}$ of aerated and continuously flowing $\left(501 \mathrm{~h}^{-1}\right)$ natural seawater at 7, 16 or $26^{\circ} \mathrm{C}$ to determine the effects of temperature on the development of the infection. Following incubation in the presence of bacteria, juvenile oysters were maintained at $16^{\circ} \mathrm{C}$ in aerated and continuously flowing natural seawater. The number of dead oysters was determined daily over a 5 to $10 \mathrm{~d}$ period, in both challenged and control oysters.

Among the juvenile oysters subjected to an injection of $10^{6} \mathrm{CFU}$ oyster ${ }^{-1}, 10$ to 12 individuals were sacrificed on Day 5 of experiments for catecholamine quantifications (see below).

Seven days after the experimental infection, oysters were examined for the presence of bacteria using the technique described above.

Stress levels and catecholamine measurements. These measurements were performed (1) on individual juvenile oysters of the RRB batch to select those presenting reduced stress-response capacities and (2) on 10 to 12 juvenile oysters among those subjected to an injection of $10^{6} \mathrm{CFU}$ oyster ${ }^{-1}$ to determine the effects of the isolated bacteria on juvenile oyster stress-response capacities. Moribund oysters and oysters presenting signs of adductor muscle weakness (gaping oysters) were excluded from these experiments.

Circulating catecholamine (CA) levels were measured in both resting oysters (controls) and in oysters submitted to a physical stress (shaking the oysters for $1 \mathrm{~min}$ ) to determine their stress-response capacities (Cueff et al. 2000, Poulet et al. 2000, Lacoste et al. 2001). Hemolymph (50 to $100 \mu \mathrm{l}$ ) was sampled from the pericardial cavity using $1 \mathrm{ml}$ syringes and $26 \mathrm{G} \times 1 / 2$ " needles. Samples were centrifuged at $600 \times g$ for $10 \mathrm{~min}$ to remove the cells from the hemolymph and cell-free supernatants were used to quantify circulating CA levels. Fifty $\mu \mathrm{l}$ of $10 \mathrm{pg}^{\mathrm{l}} \mathrm{l}^{-1}$ 3,4-dihydroxybenzylamine (DHBA) was added. CA were then extracted by absorption on alumina and CA levels were determined by liquid chromatography with electrochemical detection (Goldstein et al. 1981, Lacoste et al. 2001). The elution peaks from samples were spiked with NA, epinephrine and dopamine external standards (Sigma) for confirmation of their identity. Only NA results are presented in this report. Oysters identified as having a low NA response to stress were used to isolate poten- 
tially pathogenic bacteria. NA levels were also determined $5 \mathrm{~d}$ after the oysters had been experimentally injected with either bacterial isolates or with sterile seawater for control.

Phenotypic characterization. The bacterial strain showing pathogenic properties was characterised by standard physiological and biochemical tests using the API 20E (bioMérieux, Marcy-l'Etoile, France), according to the manufacturer's instructions with the modifications suggested by MacDonnell et al. (1982).

Genotyping. The pathogenic strain was prepared for 16S rDNA analysis.

Nucleic acid preparation: A single bacteria isolate was grown overnight on a saline media at $20^{\circ} \mathrm{C}$ (EPT $\mathrm{NaCl} 1 \%$, BioRad, Marne La Coquette, France). Cells were harvested by centrifugation $(3 \mathrm{~min}$ at $10000 \times g)$. Genomic DNA was prepared by using the Wizard Genomic DNA purification system (Promega, Madison, WI, USA) in accordance with the manufacturer's recommendations. Resuspended DNA was quantified at $260 \mathrm{~nm}$, and $50 \mathrm{ng}$ were used for the polymerase chain reaction (PCR) amplification.

PCR amplification: The PCR was carried out on a GeneAmp 2400 PCR system (Perkin Elmer Cetus, Norwalk, CN, USA) with the MicroSeq Bacteria identification kit (Perkin-Elmer Applied Biosystem Division [PE-ABD], Foster City, CA, USA). The 2 primers 0005F and 0531R - used are complementary to a phylogenetically conserved portion of the $16 \mathrm{~S}$ rDNA region and allow the $\mathrm{PCR}$ amplification of the first $527 \mathrm{bp}$ of this gene (Brosius et al. 1978). Primer forward $(0005 \mathrm{~F})$ is complementary to the $5^{\prime}$ end of the $16 \mathrm{~S}$ rRNA gene, while Primer reverse (0531R) is complementary to the 3 ' end of the opposite strand. PCR reaction was accomplished by adding $2 \mu$ of genomic DNA (50 ng) extract plus $23 \mu \mathrm{l}$ of water and $25 \mu \mathrm{l}$ of PCR Master mix which included both primers in $0.2 \mu \mathrm{l}$ MicroAmp PCR tubes (PE-ABD). A negative control (sterile deionised water) and a positive control (Escherichia coli genomic DNA) were included. The reaction was run for 35 cycles: denaturation was done at $95^{\circ} \mathrm{C}$ for $30 \mathrm{~s}$, annealing at $60^{\circ} \mathrm{C}$ for $30 \mathrm{~s}$, and extension at $72^{\circ} \mathrm{C}$ for $45 \mathrm{~s}$. An initial 10 min denaturation step at $95^{\circ} \mathrm{C}$ and a final $10 \mathrm{~min}$ extension at $72^{\circ} \mathrm{C}$ were used. The reaction mixture was held at $4^{\circ} \mathrm{C}$ until use. The PCR product was resolved for control on a $2 \%$ (wt/vol) agarose gel (Quantum Biotechnologies Inc., Montréal, Canada) in $1 \times$ TBE containing ethidium bromide, and visualized under UV light at $260 \mathrm{~nm}$. The amplification product was purified on Microcon 100 column (Amicon Millipore Corp., Bedford, MA, USA) following the manufacturer's specifications.

Cycle sequencing: Both strands of the PCR product were sequenced on an ABI Prism 377 DNA sequencer (PE-ABD) with the dRhodamine dye terminators and previously described primers. All necessary reagents were provided with the MicroSeq system and used in accordance with the manufacturer's recommendations.

Sequence data analysis: Sequence data were visually aligned and eventually corrected, with the Gene Jockey II software (Biosoft, Cambridge, UK) and converted into Pearson format. Sequence interrogation and comparison was achieved by using the search program BLAST 2.0 (Altschul et al. 1990) to explore all available DNA sequence databases (GenBank, EMBL, PDB and DDBJ).

Statistics. All data are presented as mean and standard error of at least 3 experiments, unless otherwise indicated. For comparison of 2 means, paired or unpaired Student's $t$-tests were used where appropriate. For multiple comparisons, the data were analysed by 1-way analysis of variance.

\section{RESULTS}

\section{Abundance and pathogenocity of bacterial strains}

Numerous bacterial colonies exhibiting various colors, shapes and sizes were isolated from moribund or 140 gaping juvenile oysters belonging to the 20 batches present on the experimental field site. Twenty bacterial isolates were selected among the most abundant types of colonies. Each of these 20 isolates was used in preliminary ( $\mathrm{n}=5$ oysters assay $^{-1}$ ) pathogenicity assays. None of these 20 isolates were pathogenic when injected $\left(10^{7} \mathrm{CFU}\right.$ oyster $\left.^{-1}\right)$ to juvenile oysters (Table 1).

As an alternative approach, juvenile oysters were then selected according to their stress-response capacities (Fig. 1). After application of a physical stress (shaking the oysters for $1 \mathrm{~min}$ ), circulating NA levels increased in all oysters; however, differences were noticed between oysters from different batches. In

Table 1. Crassostrea gigas. Cumulative mortality of juvenile oysters $\left(\mathrm{n}=5\right.$ oysters sample ${ }^{-1}$ ) challenged with bacterial strains isolated from moribund oysters or oysters showing signs of adductor muscle weakness. In controls, sterile seawater was injected in place of bacterial suspensions

Bacterial isolates No. of dead juvenile oysters $(n=5)$ Day 0 Day 1 Day 2 Day 3 Day 4 Day 5

\begin{tabular}{lllllll}
\hline Control & 0 & 0 & 0 & 0 & 0 & 0 \\
Isolate 1 & 0 & 0 & 0 & 1 & 1 & 1 \\
Isolate 2 & 0 & 0 & 0 & 0 & 1 & 1 \\
Isolate 3 & 0 & 0 & 0 & 0 & 0 & 0 \\
Isolate 4 & 0 & 0 & 0 & 0 & 0 & 1 \\
Isolate 5 & 0 & 0 & 0 & 0 & 0 & 0 \\
Isolates 6-20 & 0 & 0 & 0 & 0 & 0 & 0 \\
& & & &
\end{tabular}




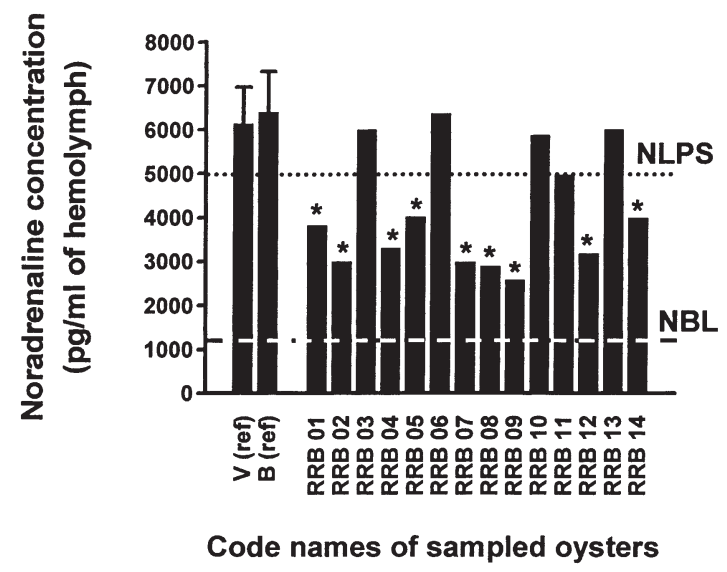

Fig. 1. Circulating noradrenaline concentrations in reference (ref) juvenile oysters (Batches $\mathrm{V}$ and $\mathrm{B}$; values are means and standard errors of 3 experiments with 10 to 12 oysters each) and in randomly sampled individuals belonging to Batch RRB. Lines indicate the normal noradrenaline basal level (NBL) and the normal noradrenaline level post-stress (NLPS) of reference batches. Stressed RRB oysters whose noradrenaline level was below the NLPS (individuals marked with a *) were selected for bacteriological analyses

reference oysters (oysters from Batches $\mathrm{V}$ and B), the noradrenaline concentration reached $6131.52 \pm$ $826.96 \mathrm{pg} \mathrm{ml}^{-1}$ of hemolymph (Batch V) and 6392.26 \pm $912.82 \mathrm{pg} \mathrm{m}^{-1}$ of hemolymph (Batch B). Taking into account both these mean values and standard errors, we considered that in healthy juvenile oysters, the normal noradrenaline concentration should be above $5000 \mathrm{pg} \mathrm{ml}^{-1}$ after the 1 min stress.

In several individuals from Batch RRB the stressinduced NA increase remained significantly $(p<0.05)$ below this normal threshold (Fig. 1). These individuals were then selected and homogenized for bacterial isolation. On Zobell plates, the number of colonies isolated from the selected RRB juvenile oysters ( 1 to $6 \times$ $10^{6} \mathrm{CFU}$ oyster ${ }^{-1}$ ) was much higher than the number of colonies isolated from the reference juvenile oysters $\left(10^{3}\right.$ to $10^{4} \mathrm{CFU}$ oyster $\left.{ }^{-1}\right)$. One particular bacterial strain, forming large yellow colonies, was dominant on TCBS plates corresponding to the selected RRB oysters whereas it was scarce or even absent in the TCBS plates corresponding to reference juvenile oysters (Batches V and B). This strain, identified as a Vibrio species since it grew on TCBS, was isolated, subcultured in liquid Zobell and processed for pathogenicity assays. Juvenile oysters that received injections of the isolated Vibrio strain at concentrations of $10^{4}, 10^{6}$ or $10^{8} \mathrm{CFU}$ oyster $^{-1}$ suffered significantly higher $(\mathrm{p}<$ 0.05 ) mortality than controls (Fig. 2a). At $26^{\circ} \mathrm{C}$ the mortality of challenged juvenile oysters was significantly higher $(\mathrm{p}<0.05)$, whereas mortality rates remained below $10 \%$ at $7^{\circ} \mathrm{C}$ (Fig. 2c,e). This temperature effect was similar to the one recorded in naturally infected oysters incubated at 16,26 or $7^{\circ} \mathrm{C}$ (Fig. $\left.2 \mathrm{~b}, \mathrm{~d}, \mathrm{f}\right)$. Incubating juvenile oysters in $300 \mathrm{ml}$ of a bacterial suspension $\left(10^{7} \mathrm{CFU} \mathrm{ml}{ }^{-1}\right)$ for 30 min had no effect on mortality (Fig. 2g), suggesting that the bacterial pathogen cannot be transmitted horizontally. Furthermore, 2 yr old oysters injected with $10^{6} \mathrm{CFU}$ oyster ${ }^{-1}$ did not suffer higher mortality than controls (Fig. 2h).

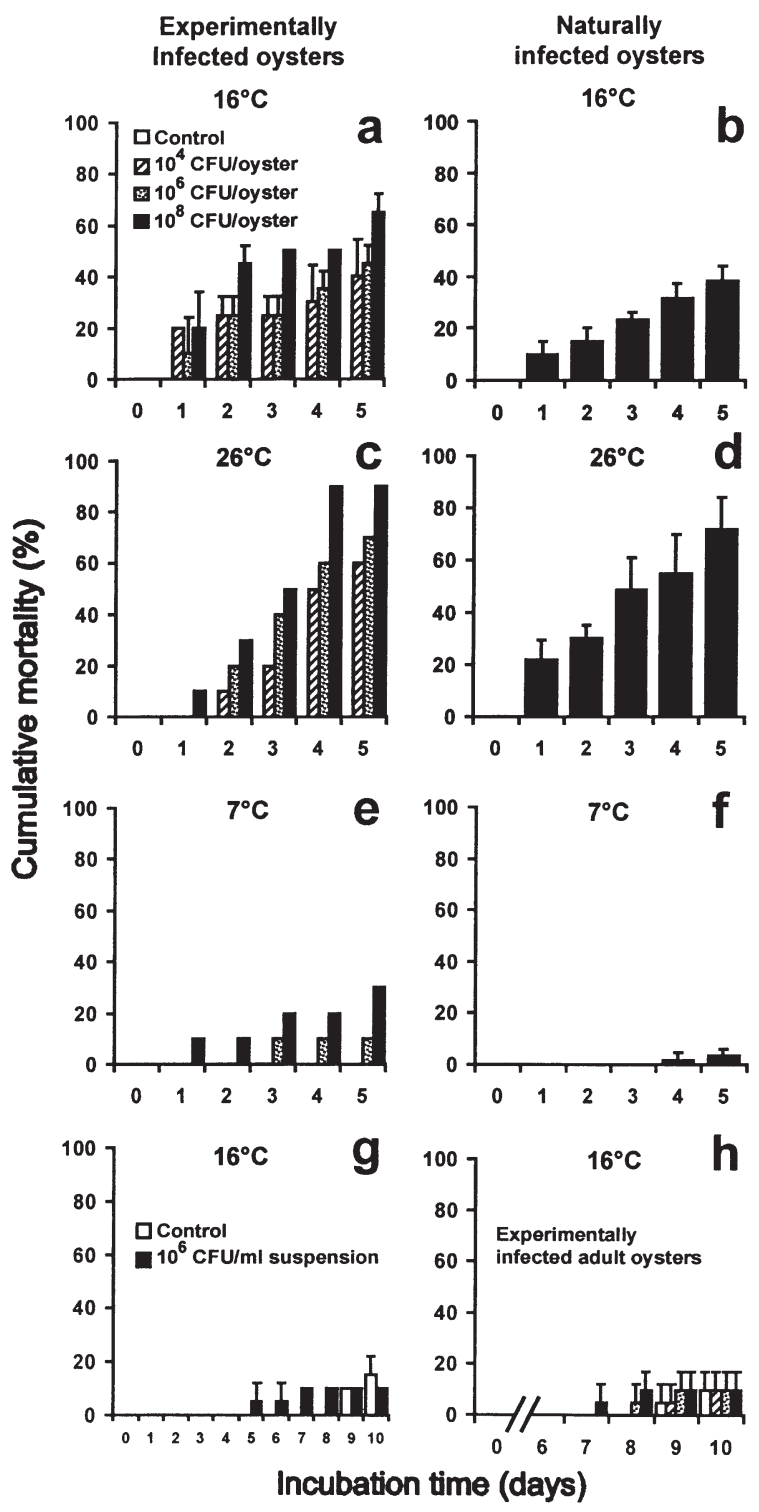

Fig. 2. Crassostrea gigas. Cumulative mortality in experimentally $(\mathrm{a}, \mathrm{c}, \mathrm{e})$ and naturally $(\mathrm{b}, \mathrm{d}, \mathrm{f})$ infected juvenile oysters incubated for $30 \mathrm{~min}$ in a bacterial suspension $\left(10^{6} \mathrm{CFU} \mathrm{ml}{ }^{-1}\right)$. Infected oysters were maintained at $16^{\circ} \mathrm{C}(\mathrm{a}, \mathrm{b}, \mathrm{g}, \mathrm{h}), 26^{\circ} \mathrm{C}(\mathrm{c}, \mathrm{d})$ or $7^{\circ} \mathrm{C}(\mathrm{e}, \mathrm{f})$. (g) Cumulative mortality in challenged adult oysters. In controls, sterile seawater was used in place of bacterial suspensions (h). As shown, sterile seawater induced very little or no mortality. Values are means and standard errors of 3 replicates except in (c) and (e), which are single experiments. All experiments were performed on 20 to 30 oysters 


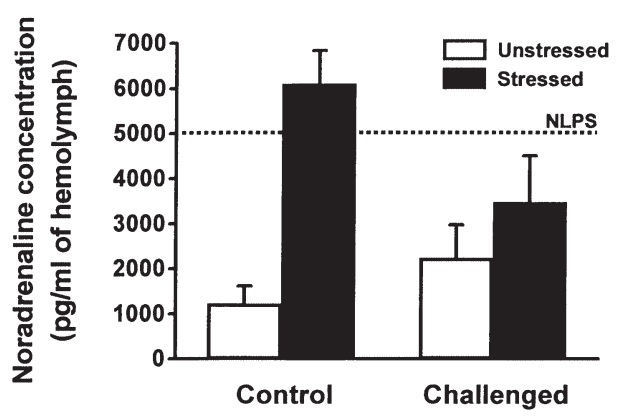

Fig. 3. Circulating noradrenaline concentrations in both resting and stressed oysters $5 \mathrm{~d}$ after injection of sterile seawater (Control) or challenged $\left(10^{6} \mathrm{CFU}\right.$ oyster $\left.^{-1}\right)$ with the isolated Vibrio strain (Challenged). The dotted line indicates the normal noradrenaline level post-stress (NLPS) of reference batches (see Fig. 1). Values are means and standard errors of

3 replicates (10 to 12 juvenile oysters in each replicate)

NA quantifications showed that 4 to $5 \mathrm{~d}$ after challenge, juvenile oysters exhibited significantly $(p<0.05)$ impaired stress-response capacities (Fig. 3). Furthermore, phenotypic and genotypic characterizations (see below) indicated that the same pathogenic Vibrio strain could be re-isolated from these juvenile oysters.

\section{Phenotypic and genotypic characterizations}

Results in Table 2 present physiological and biochemical characteristics of the isolated bacterial strain. This strain exhibited features of bacteria belonging to the genus Vibrio (Alsina et al. 1994). Sequencing of the 16S rDNA revealed that the input sequence produced a significant alignment with the following referenced sequences: $100 \%$ gblU64024.1/VSU64024 Vibrio sp. 16S ribosomal RNA gene and 99\% emblZ31657IVS16SRRN $V$. splendidus (SCB8) gene for 16S ribosomal RNA.

\section{DISCUSSION}

During the summer of 1999, 30 different stock-populations of juvenile oysters Crassostrea gigas were monitored in the Bay of Morlaix. One-third of these populations exhibited high mortality rates (40 to $80 \%$ ) and the remaining two-thirds suffered little or no mortality (0 to $15 \%$ ). Preliminary studies (Poulet et al. 2000) revealed that, as demonstrated earlier with Crassostrea virginica (Boettcher et al. 1999, Elston 1999b), antibiotic-treated juvenile oysters C. gigas suffered lower mortalities than untreated ones. This result suggested that a bacterial pathogen could be involved in the summer mortality of juvenile C. gigas in the Bay of Morlaix.
First attempts failed to isolate a bacterial pathogen from moribund or gaping oysters belonging to 20 batches placed on an experimental field site in the Bay of Morlaix (Table 1). Thus, a new approach was used where bacterial strains were isolated from juvenile oysters showing impaired neuroendocrine responses to an experimentally induced stress (shaking the oysters for $1 \mathrm{~min}$ ). Previous studies have demonstrated that noradrenaline increases in the hemolymph of stressed oysters (Lacoste et al. 1999, 2001). In oysters entering an early phase of the disease, this stressinduced noradrenaline increase is reduced (Lacoste et al. 2000), suggesting that an impaired stress response capacity is an early symptom of the juvenile oyster summer mortality disease.

In the present study, juvenile oysters exhibiting this early symptom were selected (Fig. 1) and a bacterial strain belonging to the genus Vibrio was isolated from the selected animals. This strain exhibited pathogenic properties when injected to healthy juvenile oysters at concentrations of $10^{4}, 10^{6}, 10^{8} \mathrm{CFU}$ oyster $^{-1}$ (Fig. 2a).

Table 2. Phenotypic characteristics of the isolated Vibrio splendidus strain as determined using API 20E galleries

\begin{tabular}{|lc|}
\hline Tests & Results \\
\hline Gram & - \\
Motility & - \\
Swarming & + \\
Growth on TCBS & + \\
Use of & \\
Citrate & - \\
Glucose & + \\
Mannitol & + \\
Inositol & - \\
Sorbitol & - \\
Rhamnose & - \\
Saccharose & + \\
Melibiose & + \\
Amygdaline & + \\
Arabinose & - \\
Enzymes & \\
Hydrolysine ONPG & - \\
Arginine dihydrolase & - \\
Lysine decarboxylase & - \\
Ornithine decarboxylase & - \\
Urease & - \\
Tryptophane deaminase & - \\
Gelatinase & - \\
Cytochrome oxydase & - \\
Production of & - \\
$\mathrm{H}_{2}$ S & - \\
Indole & - \\
Acetoine (Voges-Proskauer) & - \\
NO & \\
Glucose oxydation & - \\
Glucose fermentation & + \\
& \\
& - \\
\hline
\end{tabular}


Moreover, mortality rates of experimentally infected oysters increased at higher temperatures (Fig. 2c) and decreased at lower temperatures (Fig. 2e). This temperature effect is also observed in naturally infected oysters (Fig. 2b,c,d). These results are consistent with the well-accepted idea that multiplication of bacteria and mollusc mortality are linked and temperaturedependent (Friedman et al. 1991, Riquelme et al. 1995, Lee et al. 1996).

The present results also show that juvenile oysters incubated in a suspension of the isolated Vibrio did not suffer mortality higher than controls (Fig. 2g). Previous experiments have shown that healthy juveniles do not suffer higher mortalities when grown on oyster fields next to juveniles exhibiting high mortality (Poulet et al. 2000). Taken together, these results suggest that the bacteria cannot be transmitted horizontally.

In addition, experimentally infected 2 yr old oysters did not suffer significant mortality (Fig. 2h), which is consistent with other studies showing that oyster summer mortalities affect 6 to 12 mo old juvenile oysters but not older specimen (Martin et al. 1999, Poulet et al. 2000).

The use of hormonal stress indicators showed that 4 to $5 \mathrm{~d}$ after challenge, infected juvenile oysters exhibited reduced stress-response capacities (Fig. 3). This result indicated that the isolated Vibrio strain induced similar symptoms to the ones observed in naturally infected juvenile oysters. Moreover, the bacterial pathogen was re-isolated from experimentally infected juvenile oysters. Taken together, these results satisfy Koch's postulate and suggest that the isolated Vibrio is a probable causative agent of the juvenile Crassostrea gigas mortalities observed in the Bay of Morlaix during summer 1999.

Phenotypic (Table 2) and genotypic characterizations permitted identification of the pathogen as Vibrio splendidus. Vibriosis is known to affect a wide range of fish (Egidius 1987, Diggles et al. 2000), crustacean (Leano et al. 1998) and shellfish (Jeffries 1982, Bolinches et al. 1986, Borrego et al. 1996, Nicolas et al. 1996, Lambert et al. 1998). V. splendidus has been associated with turbot larvae mortalities (Farto et al. 1999, Gatesoupe et al. 1999) and scallop diseases (Lambert et al. 1999). In oysters, V. splendidus has been isolated from Crassostrea virginica and C. gigas larvae exhibiting high mortality in hatcheries (Sugumar et al. 1998, Elston 1999a,b). In adult oysters, V. splendidus was shown to accumulate notably in the gonad, which led Sugumar et al. (1998) to suggest that this pathogen could be transmitted vertically.

Further work is in progress to determine the prevalence of this Vibrio splendidus strain in oyster stocks cultured in the Bay of Morlaix. To date, it appears that this particular strain was detected in all the monitored oyster stocks that suffered high mortalities during the summer of 1999. Repetition of the experiments during summer 2000 confirmed these results.

Recent studies have shown that oyster defenses against bacterial pathogens such as vibrios are influenced both by environmental and physiological parameters (Volety et al. 1999). Furthermore, the outbreak of disease and stress are linked in molluscs (Bricelj et al. 1992, Lee et al. 1996, Friedman et al. 1999, Cheney et al. 2000). As a consequence, possible relations between environmental factors, the physiological state of the juvenile oysters and the pathogenicity of the bacteria are under investigation. The mode of action of this pathogen is also being studied.

Acknowledgements. This work was supported by grants from the 'Conseil Régional de Bretagne', 'Département du Finistère, Côtes d'Armor et Ille-et-Vilaine' and the 'Section Régionale Conchylicole de Bretagne Nord'. We would like to thank the oyster farmers of Northern and Southern Brittany, who provided us with samples and helpful information. We would also like to thank R. Pajot and P. Trintignac from SMIDAP and A. Marécat from the Pasteur Institute for their cooperation.

\section{LITERATURE CITED}

Alsina M, Blanch AR (1994) A set of keys for biochemical identification of environmental Vibrio species. J Appl Bacteriol 76:79-85

Altschul SF, Gish W, Miller W, Myers EW, Lipman DJ (1990) Basic local alignment search tool. J Mol Biol 215:403-410

Boettcher KJ, Barber BJ, Singer JT (1999) Use of antibacterial agents to elucidate the etiology of juvenile oyster disease (JOD) in Crassostrea virginica and numerical dominance of an $\alpha$-proteobacterium in JOD-affected animals. Appl Environ Microbiol 65:2534-2539

Bolinches J, Toranzo AE, Silva A, Barja JL (1986) Vibriosis as the main causative factor of heavy mortalities in the oyster culture industry in Northwestern Spain. Bull Eur Assoc Fish Pathol 6:1-3

Bricelj VM, Ford SE, Borrero FJ, Perkins FO, Rivara G, Hillman RE, Elston RA, Chang J (1992) Unexplained mortalities of hatchery-reared, juvenile oysters, Crassostrea virginica (Gmelin). J Shellfish Res 11:331-347

Borrego JJ, Luque A, Castro D, Santamaria JA, MartinezManzanares E (1996) Virulence factors of Vibrio P1, the causative agent of brown ring disease in the Manila clam, Ruditapes philippinarum. Aquat Living Resour 9:125-136

Brosius J, Palmer ML, Kennedy PJ, Noller HF (1978) Complete nucleotide sequence of a $16 \mathrm{~S}$ ribosomal RNA gene from Escherichia coli. Proc Natl Acad Sci USA 10: 4801-4805

Cheney DP, MacDonald BF, Elston RA (2000) Summer mortality of Pacific oysters, Crassostrea gigas (Thunberg): initial findings on multiple environmental stressors in Puget Sound, Washington, 1998. J Shellfish Res 19:353-359

Cueff A, Lacoste A, Malham SK, Jalabert F, Gélébart F, Poulet SA (2000) Is summer mortality of the juvenile oysters Crassostrea gigas linked to their physical and chemical characteristics? The Annual International Conference and Exposition of the World Aquaculture Society, Book of 
Abstracts, Ostend, p 159

Deslou-Paoli J-M, Heral M, Berthome JP, Razet D, Garnier J (1982) Reproduction naturelle de Crassostrea gigas Thunberg dans le bassin de Marennes-Oleron en 1979 et 1981: aspects biochimiques et énergétiques. Rev Trav Inst Pêches Marit 45:319-327

Diggles BK, Carson J, Hine PM, Hickman RW, Tait MJ (2000) Vibrio species associated with mortality in hatcheryreared turbot (Colistium nudipinnis) and brill (C. guntheri) in New Zealand. Aquaculture 183:1-12

Egidius E (1987) Vibriosis: pathogenicity and pathology. A review. Aquaculture 67:15-28

Elston RA (1999a) Acute pallial bacterial infection, bacillary necrosis, and vibriosis. In: Browdy CL (ed) Health management, development and histology of seed oysters. World Aquaculture Society, Baton Rouge, LO, p 57-65

Elston RA (1999b) Chronic extrapallial abscesses of juvenile oysters. In: Browdy CL (ed) Health management, development and histology of seed oysters. World Aquaculture Society, Baton Rouge, LO, p 87-89

Farto R, Montes M, Pérez MJ, Nieto TP, Larsen JJ, Pedersen K (1999) Characterization by numerical taxonomy and ribotyping of Vibrio splendidus biovar I and Vibrio scophthalmi strains associated with turbot cultures. J Appl Microbiol 86:796-804

Friedman CS, Beattie JH, Elston RA, Hedrick RP (1991) Investigation of the relationship between the presence of a Gram-positive bacterial infection and summer mortality of the Pacific oyster, Crassostrea gigas Thunberg. Aquaculture 94:1-15

Friedman CS, Cherr GN, Clegg JS, Hamdoun AH, Jacobsen JL, Jackson SA, Uhlinger KR (1999) Investigation of the stress response, summer mortality and disease resistance of oysters, Crassostrea gigas and Crassostrea virginica. J Shellfish Res 18:297 (Abstract)

Gatesoupe FJ, Lambert C, Nicolas JL (1999) Pathogenicity of Vibrio splendidus strains associated with turbot larvae, Scophthalmus maximus. J Appl Microbiol 87:757-763

Goldstein DS, Feuerstein C, Izzo JL, Kopin IJ, Keiser HR (1981) Validity and reliability of liquid chromatography with electrochemical detection for measuring plasma levels of norepinephrine and epinephrine in man. Life Sci 28: $467-475$

Jeffries V (1982) Three Vibrio strains pathogenic to larvae of Crassostrea gigas and Ostrea edulis. Aquaculture 29: 201-226

Lacoste A, Malham SK, Cueff A, Jalabert F, Gélébart F, Poulet SA (1999) Indicators for the early detection of stress in the oyster Crassostrea gigas. The Annual International Conference and exposition of the World Aquaculture Society, Book of Abstracts, Sydney, p 418

Lacoste A, Malham SK, Cueff A, Jalabert F, Gélébart F, Poulet SA (2000) Stress as a potential triggering factor of juvenile

Editorial responsibility: Albert Sparks, Seattle, Washington, USA oyster summer mortalities. The Annual International Conference and Exposition of the World Aquaculture Society. Book of Abstracts, p 360

Lacoste A, Malham SK, Cueff A, Jalabert F, Gélébart F, Poulet SA (2001) Evidence for a form of adrenergic response to stress in the mollusc Crassostrea gigas. J Exp Biol 204: $1247-1255$

Lambert C, Nicolas JL, Cilia V, Corre S (1998) Vibrio pectinicida sp. Nov., a pathogen of scallop (Pecten maximus) larvae. Int J Syst Bacteriol 48:481-487

Lambert C, Nicolas JL, Cilia V (1999) Vibrio splendidusrelated strain isolated from brown deposit in scallop (Pecten maximus) cultured in Brittany (France). Bull Eur Assoc Fish Pathol 19:102-106

Leano EM, Lavilla-Pitog CR, Paner MG (1998) Bacterial flora in the hepatopancreas of pond-reared Penaeus monodon juveniles with luminous vibriosis. Aquaculture 164: 367-374

Lee M, Taylor GT, Bricelj M, Ford SE, Zahn S (1996) Evaluation of Vibrio spp. and microplankton blooms as causative agents of juvenile oyster disease in Crassostrea virginica (Gmelin). J Shell Res 15:319-329

MacDonnell MT, Singleton FL, Hood MA (1982) Diluent composition for use of API 20E in characterising marine and estuarine bacteria. Appl Environ Microbiol 44:423-427

Martin AG, Mazurié G, Tigé G, Hirata T, Kuntz G, LeCognic MJ, Le Mouroux G (1999) Surveillance des maladies et étude des mortalités anormales des coquillages. Synthèse des résultats 1994-1998. Rapport Ifremer, No. RA/LCB/ 99-08, La Trinité/Mer

Nicolas JL, Corre S, Gauthier G, Robert R, Ansquer D (1996) Bacterial problems associated with scallop Pecten maximus larval culture. Dis Aquat Org 27:67-76

Poulet SA, Jalabert F, Cueff A, Malham SK, Gélébart F, Lacoste A (2000) Etude et contrôle de la mortalité des juvéniles de l'huître Crassostrea gigas. Rapport Gigasmor No. 3, CNRS, Roscoff

Riquelme C, Hayashida G, Toranzo AE, Vilches J, Chavez P (1995) Pathogenicity studies on a Vibrio anguillarumrelated (VAR) strain causing an epizootic in Argopecten purpuratus larvae in Chile. Dis Aquat Org 22:135-141

Soletchnik P, Le Moine O, Faury N, Razet D, Geairon P, Goulletquer P (1998) Summer mortality of the oyster in the Bay Marennes-Oleron: spatial variability of environnement and biology using a geographical information system (GIS). Aquat Living Resour 12:131-143

Sugumar G, Nakai T, Hirata Y, Matsubara D, Muroga K (1998) Vibrio splendidus biovar II as the causative agent of bacillary necrosis of Japanese oyster Crassostrea gigas larvae. Dis Aquat Org 33:111-118

Volety AK, Winstead JT, Fisher WS (1999) Influence of seasonal factors on oyster hemocyte killing of Vibrio parahemolyticus. J Shellfish Res 18:323 (Abstract)

Submitted: October 9, 2000; Accepted: May 3, 2001

Proofs received from author(s): August 14, 2001 